\title{
URGENSI BIMBINGAN DAN KONSELING ISLAM BAGI LANJUT USIA
}

\begin{abstract}
Asniti Karni*
Abstract

Elderly can be said as golden age because not everyone can reach old age, so if someone has old age will require more nursing actions, both promotive and preventive, so that he can enjoy the golden age, as well as a useful old age and happy. On the contrary of old age if there is no intensive care of his family then he can not enjoy his golden age with happy. While the elderly are individuals aged 6065 years old and above, meaning individuals who have the ability to live and sensitivity individually weak, both weak to the physical condition and weak to adjust to the environment. The existing conditions in the elderly tend to potentially cause physical health problems and mental health. Therefore it is necessary guidance and counseling Islam in order to help alleviate the problems it faces. So that the elderly in their daily lives become effective and can think that he is still useful and needed others and has the potential to stick to Islamic values.
\end{abstract}

Kata Kunci: Bimbingan dan Konseling Islam, Lansia

\section{Pendahuluan}

Individu lanjutusiaumumnyamemiliki sikap yang lemah, baik lemah terhadap kondisi fisik maupun lemah menyesuaikan dengan lingkungannya. Yang perlu digaris bawahi adalah meraih usia panjang tidak hanya persoalan untuk menjaga fisik pada lansia, tetapi yang lebih penting adalah mental seseorang dalam menyikapi rentang hidupnya. Seperti halnya usia lanjut di sini mereka harus mampu menyikapi rentang hidupnya dengan berusaha memahami keadaan yang ada pada dirinya.

Keadaan yang ada pada lansia cenderung berpotensi menimbulkan masalah kesehatan secara umum maupun kesehatan

* Penulis adalah Dosen Dakwah IAIN Bengkulu secara khusus, baik kesehatan fisik maupun kesehatan jiwa. Oleh karena itu diperlukan bimbingan dan konseling Islam kepada lansia agar dapat menerima keadaan dengan mencari sisi positif dari kemampuan dan pengalaman yang ada pada lansia, agar ia berfikir bahwa ia masih berguna dan dibutuhkan orang lain.

Namun pada kenyataanya, dengan kulit keriput, fisik renta, sakit-sakitan, langkah gontai, pakaian kusut, bahkan kadang cacat fisik, orang lanjut usia itu mengharap belas kasih orang lain bahkan kadang dieksploitasi oleh pihak tertentu. Sementara dirumah mewah dijumpai lansia yang merasa sudah 
tidak berguna, diacuhkan oleh keluarganya, kehilangan kekuasaan, dan sakit-sakitan.

Oleh karena itu pelayanan Bimbingan dan Konseling Islam pada lansia tidak dapat dilakukan sendiri oleh konselor. Konselor perlu bekerja sama dengan berbagai pihak dan adanya asas keterpaduan, terutama peran yang sangat besar dari anggota keluarga.

\section{Lansia}

Lansia adalah tahap akhir perkembangan pada daur kehidupan manusia dan ditandai oleh gagalnya seorang untuk mempertahankan keseimbangan kesehatan dan kondisi stres fisiologis nya. Lansia juga berkaitan dengan penurunan daya kemampuan untuk hidup dan kepekaan secara individual. Selain pengertian lansia secara umum di atas, terdapat juga beberapa pengertian lansia menurut para ahli. Usia lanjut juga dapat dikatakan sebagai usia emas karena tidak semua orang dapat mencapai usia lanjut tersebut, maka jika seseorang telah berusia lanjut akan memerlukan tindakan keperawatan yang lebih, baik yang bersifat promotif maupun preventif, agar ia dapat menikmati masa usia emas serta menjadi usia lanjut yang berguna dan bahagia. Jika dilihat dari segi usia, batasan usia lansia berkisar di atas 60 atau 65 tahun ke atas, adapun acuan yang dijadikan alasan dalam menentukan masa lansia ini adalah alasan ekonomi, seperti sudah pensiun, dan pembebasan pajak penghasilan. $^{1}$

\section{Tugas Perkembangan Lansia}

Sebagaimana periode atau tahapan perkembangan sebelumnya, pada tahap lansia juga memiliki tugas-tugas perkembangan yaitu kemampuan serta keterampilan yang dimiliki seseorang sesuai dengan prode usianya.

Adapun tugas perkembangan lansia menurut Havighurts (dalam Hurlock)2:

a) Mampu melakukan penyesuaian terhadap kekuatan fisik yang menurun.

b)Mampu melakukan penyesuaian diri dengan kematian teman hidup.

c)Mampu menemukan relasi dengan teman kelompok sebaya.

d) Mampu melakukan kewajiban-kewajiban sosial dan warga negara.

e) Mampu melakukkan penyesuaian dengan gaji yang berkurang dan keadaan pensiun.

f) Mampu merealisasikan keadaan hidup fisik yang sesuai.

Sejalan dengan pendapat di atas, menurut Erikson tugas perkembangan lansia diantaranya yaitu; a) Memperoleh kepuasan dalam keluarga sebagai tempat tinggal dihari tua, b) menyesuaikan hidup dengan penghasilan sebagai pensiun, c) Mampu membina kehidupan rutin yang menyenangkan, d) mampu melakukkan 
hubungan dengan anak dan cucu-cucu, d) mampu mengembangkan minat dan perhatian terhadap orang di luar keluarga, mampu menemukan arti hidup. ${ }^{3}$

\section{Masalah-Masalah Lansia}

Proses perkembangan manusia dipengaruhi oleh kesuksesan perkembangan sebelumnya, kondisi priode perkembangan individu yang terhambat sebelumnya akan menimbulkan masalah pada masa priode lansia, ada beberapa yang menjadi masalah yang sering terjadi pada lansia, yaitu menurunnya kondisi fisik dan psikologis pada lansia merupakan faktor alami yang tidak dapat dicegah tetapi dapat diperlambat atau dipercepat tergantung kepada lansia yang bersangkutan, pola makan, lingkungan dan keturunan.

Masalah kondisi fisik yang menurun karena disebabkan oleh faktor usia merupakan masalah yang umum dan sangat wajar dialami oleh lansia, namun kondisi ini memerlukan penyesuain yang baik pada lansia, sehingga pada masa tuanya tetap sehat, bahagia dan memiliki kepercayaan diri yang baik, masalah psikis yang cenderung terjadi pada masa lansia, ${ }^{4}$ adalah sebagai berikut; a) Kecemasan dan ketakutan yang muncul misalnya cemas akan perubahan fisiknya dan fungsi anggota tubuh, cemas akan kekuatan sosial, cemas akan tersingkir dari kehidupan sosial, takut penyakit, takut mati, takut kekurangan uang, b) Suasana hati lansia cenderung peka, mudah tersinggung dan cepat berubah. Perasaan penuh dengan ketegangan, gelisah dan sikap banyak menuntut, bahkan kadang kala terjadi ledakan emosional yang penuh kecurigaan. c) rasa kesepian karena jauh dari keluarga dan anakanak, serta sedikitnya teman yang seusia, d) dan kehilangan kepercayaan diri, akibat dari menurunya produksipitas dan kondisi fisik yang menurun.

\section{Ciri-ciri Lansia}

Menurut Hurlock terdapat beberapa ciri-ciri orang lanjut usia, yaitu: ${ }^{5}$

a. Usia lanjut merupakan periode kemunduran.

Kemunduran pada lansia sebagai datang dari faktor fisik dan faktor psikologis. Kemunduran dapat berdampak pada psikologis lansia. Motivasi memiliki peran yang penting dalam kemunduran pada lansia. Kemunduran pada lansia semakin cepat apabila memiliki motivasi yang rendah, sebaliknyajika memilikimotivasi yang kuat maka kemunduran itu akan lama terjadi.

b. Orang lanjut usia memiliki status kelompok minoritas.

Lansia memiliki status kelompok minoritas karena sebagai akibat dari sikap 
sosial yang tidak menyenangkan terhadap orang lanjut usia dan diperkuat oleh pendapat-pendapat klise yang jelek terhadap lansia. Pendapat - pendapat klise itu seperti : lansia lebih senang mempertahankan pendapatnya dari pada mendengarkan pandapat orang lain.

c. Menua membutuhkan perubahan peran.

Perubahan peran tersebut dilakukan karena lansia mulai mengalami kemunduran dalam segala hal. Perubahan peran pada lansia sebaiknya dilakukan atas dasar keinginan sendiri bukan atas dasar tekanan dari lingkungan.

d. Penyesuaian yang buruk pada lansia

Perlakuan yang buruk terhadap orang lanjut usia membuat lansia cenderung mengembangkan konsep diri yang buruk. Lansia lebih memperlihatkan bentuk perilaku yang buruk, karena perlakuan yang buruk itu membuat penyesuaian diri lansia menjadi buruk.

\section{Kondisi Fisik Pada Lansia}

Pola hidup sangat mempengaruhi penampilan untuk menjadi awet muda dan panjang umur atau sebaliknya. Mengatur pola makan setelah berusia 40 tahun keatas, sangatlah penting. Asupan gizi seimbang sangat diperlukan tubuh jika ingin awet muda dan berusia lanjut dalam keadaan tetap sehat. Tidak dapat disangkal, banyak kendala yang dihadapi manusia saat memasuki pertambahan usia dan mulai menua. Terutama bila sejak muda tidak menerapakan pola hidup sehat atau sudah terserang beragam penyakit seperti stroke, hipertensi, jantung, dan sebagainya. Bahkan ketajaman penglihatan manusia sudah berkurang sejak berusia 40 tahun. Kemampuan tersebut berkurang terutama untuk melihat jarak dekat sehingga memerlukan kaca mata berlensa cembung. Keadaan ini tidak dapat dihindari, namun mudah di atasi dengan menggunakan kacamata. Penyebabnya bisa bermacammacam namun lebih sering karena ketuaan itu sendiri dan akibat hipertensi. ${ }^{6}$

Masa tua bagi sebagian masyarakat adalah masa-masa yang menakutkan oleh karena itu berbagai upaya dilakukan untuk menyiapkan investasi kesehatan diusia tua. Penuaan adalah sebuah proses alami. Setiap orang akan mengalami fase yang mengarah kepada penuaan. Seseorang dianggap berhasil menjalani proses penuaan jika dapat terhindar dari berbagai penyakit, organ tubuhnya dapat berfungsi dengan baik, serta kemampuan berfikirnya atau kognitif masih tajam. Para lansia yang berhasil mempertahankan fungsi gerak dan berfikirnya dianggap berhasil menghadapi penuaan sehingga dapat bekerja aktif terutama disektor informal. Mereka biasanya dapat berbagi pengalaman dan telah mencapai 
tahap perkembangan psikologis dimana mereka dianggap bijaksana menyikapi kehidupan dan mendalami kehidupan spiritual. $^{7}$

Agar tetap aktif sampai tua, sejak muda seseorang perlu melakukan mempertahankan kemudian pola hidup sehat dengan menkonsumsi makanan yang bergizi seimbang, melakukan aktifitas fisik atau olahraga secara benar dan teratur dan tidak merokok. Rencana hidup yang realistis seharusnya sudah dirancang jauh sebelum memasuki masa lanjut usia, paling tidak individu sudah punya bayangan aktivitas apa yang akan dilakukan kelak bila pensiun sesuia dengan kemampuan dan minatnya. Berdasarkan prinsip tersebut maka lanjut usia merupakan usia yang penuh kemandirian baik dalam tingkah laku kehidupan sehari-hari, bekerja maupun berolahraga. Dengan menjaga kesehatan fisik, mental, spiritual, ekonomi, dan social, seseorang dapat memilih masa tua yang lebih membahagiakan, terhindar dari banyak masalah kesehatan. ${ }^{8}$

Setelah orang memasuki masa lansia umumnya mulai dihinggapi adanya kondisi fisik yang bersifat patologis berganda (multiple pathology), misalnya tenaga berkurang, energi menurun, kulit mulai keriput, gigi mulai rontok, tulang makin rapuh, dan sebagainya. Secara umum kondisi fisik seseorang yang sudah memasuki masa lansia mengalami penurunan secara berlipat ganda. Ini semua dapat menimbulkan gangguan atau kelainan fungsi fisik, psikologis maupun sosial, yang selanjutnya dapat menyebabkan suatu keadaan ketergantungan kepada orang lain.

\section{Bimbingan dan Konseling Islam Bagi}

\section{Lansia}

Pelayanan Bimbingan dan Konseling Islam secara professional pada lanjut usia belum banyak dilakukan. Berbagai pelayanan terhadap lansia, baik oleh anak-anaknya, lembaga keagamaan. LSM, umumnya dilakukan tidak secara utuh, yang kadangkala kurang memahami permasalahan lansia secara menyeluruh. Di lembaga keagamaan misalnya lebih menekankan aspek spiritual, di pusatpusat rehabilitasi sosial khususnya di Panti Werda sudah diupayakan pelayanan secara optimal, namun penekanannya masih dalam aspek fisik kesehatan. Kesulitan dalam pelayanan Bimbingan dan Konseling Islam bagi lansia juga diakui oleh George dan Cristiani (1981), dan menuntut program pelatihan khusus bagi konselor yang melayani usia lanjut.

Ajaran Islam yang bersumber dari Al Qur'an dan Hadist memberikan tempat yang sangat terhormat bagi lansia. Orang tua ibarat “tuhan yang kelihatan”, dalam hadist disebutkan bahwa "keridlaan Allah terletak pada keridlaan orang tua dan kemurkaan 20 
maupun lingkungan sosial dan alam sekitarnya.

3. Untuk menghasilkan kecerdasan rasa (emosi) pada individu sehingga muncul dan berkembang rasa toleransi, kesetiakawanan, tolong-menolong dan rasa kasih sayang.

4. Untuk menghasilkan kecerdasan spiritual pada diri individu sehingga muncul dan berkembang rasa keinginan untuk berbuat taat kepada Tuhannya, ketulusan mematuhi segala perintahNya serta ketabahan menerima ujianNya.

5. Untuk menghasilkan potensi Ilahiyah, sehingga dengan potensi itu individu dapat melakukan tugasnya sebagai khalifah dengan baik dan benar; ia dapat dengan baik menanggulangi berbagai persoalan hidup; dan dapat memberikan kemanfaatan dan keselamatan bagi lingkungannya pada berbagai aspek kehidupan.

6. Untuk mengembalikan pola pikir dan kebiasaan konseli yang sesuai dengan petunjuk ajaran islam (bersumber pada Al-Quran dan paradigma kenabian.

Bidang Layanan Bimbingan dan Konseling Islam

Kalau dalam menentukan bidangbidang pelayanan Bimbingan dan konseling ini mengikuti dimensi yang ada pada manusia sebagai makhluk multidimensi, maka bidang pelayanan Bimbingan dan konseling Islami bisa pula dikembangkan. Kalau manusia multidimensi itu adalah makhluk jasmani, rohani, beragama, berakhlak, social, berakal dan estetika, tentu ada pula bidang bimbingan jasmani, bimbingan agama, bimbingan estetika, bimbingan pengembangan akal.

Khusus tentang dimensi agama, oleh karena agama itu sangat berpengaruh dalam segala aspek dan aktivitas kehidupan manusia, maka bidang bimbingan agama sangat wajar dijadikan salah satu bidang dalam Bimbingan dan konseling. Bimbingan dan konseling agama sebagai salah satu bidang atau disiplin ilmu bimbingan dan konseling, substansi keduanya tidaklah jauh berbeda pengertiannya, perbedaannya hanya terletak pada isi dan pendekatan. Pada substansinya, baik bimbingan dan konseling agama maupun bimbingan dan konseling umum adalah pelayanan bantuan kemanusiaan atau pemberian nasehat dalam makna luas dalam bahasa agama kepada manusia, baik secara individu atau kelompok. Sedangkan pada esensi utamanya adalah usaha untuk memanusiakan manusia, amar makruf dan nahi mungkar.

Bukan bimbingan dan konseling namanya, apa pun bidang bimbingan dan konselingnya, kalau dalam kegiatannya tidak berupaya memanusiakan manusia dan 
berupaya amar makruf nahi mungkar. Yahya Jaya menyatakan ada 4 jenis bidang bimbingan dan konseling Islami sesuai dengan pembagian aspek agama Islam itu sendiri. ${ }^{16}$ Dalam wujud yang lebih jelas keempat ruang lingkup bidang pelayanan bimbingan dan konseling Islami itu dapat dikemukakan sebagai berikut:

1) Bimbingan Akidah

Bimbingan akidah adalah bidang pelayanan yang membantu konseling dalam mengenal, memahami, menghayati, mengamalkan, dan mengembangkan akidah keimanannya, sehingga menjadi pribadi yang beriman dan bertakwa kepada Allah SWT, mantap (istiqamah), dan mandiri (alkaiyis), sehat dan bahagia, baik lahiriah maupun batiniah, berdasarkan rukun Islam yang enam. Pribadi muwahid adalah tujuan tertingginya.

2) Bimbingan Ibadah

Bimbingan ibadah adalah bidang layanan yang membantu klien dalam mengembangkan hubungan dan pengabdiannya kepada Allah melalui amal ibadah agar menjadi pribadi yang taat dalam mengerjakan perintahperintah-Nya dan taat dalam menjauhi larangan-larangan-Nya. Pembentukan manusia abid (ahli ibadah) adalah tujuan tertinggi dari pelayanan bimbingan ibadah.
3) Bimbingan Akhlak

Bimbingan akhlak adalah bidang pelayanan yang membantu konseli dalam mengembangkan sikap dan perilaku yang baik, sehingga memiliki akhlak mahmuda dan jauh dari akhlak mazmumah. Tujuan yang hendak dicapai oleh bidang bimbingan ini pribadi mulia.Khuluq'azhim atau makarim al akhlaq dalam bahasa al-Qur'an dan hadits.

4) Bimbingan Muamalah

Bimbingan muamalah adalah bidang pelayanan yang membantu klien dalam membina dan mengembangkan hubungan yang selaras, serasi dan seimbang dengan sesama manusia dan makhluk, sehingga memiliki keharmonisan dalam kehidupan beragama.

\section{Jenis-jenis Pelayanan Bimbingan dan}

\section{Konseling Islam}

a) Layanan Orientasi Agama

Layanan orientasi agama adalah layanan yang memungkinkan umat mengenal dan memahami lingkungan keberagamaannya dari orang-orang yang dapat memberikan pengaruh agama untuk mempermudah orang berperan di lingkungan hidup keberagamaan yang baru dimasukinya. Misalnya orang yang 
akan masuk Islam. Sebelum mengucapkan dua kalimat syahadat, adalah sangat hikmat dan bijaksana, kalau diperkenalkan lebih dahulu makna dan hakikatnya dua kalimat syahadat yang diucapkan itu. Dengan cara demikian diharapkan orang terjauh dari sifat keterpaksaan dalam menganut agama, dengan demikian orang mudah menyesuaikan diri dengan lingkungan keberagamaannya. Dan menjadikan agama sebagai kebutuhan jiwa dan sumber kebahagiaan hidup. Disamping materi akidah yang dapat di angkat melalui orientasi agama, materi ibadah, akhlak dan muamalah bisa pula diangkat.

b) Layanan Informasi Agama

Layanan informasi agama adalah Jenis layanan yang memungkinkan umat atau orang yang beragama menerima dan memahami informasi keberagamaannya dari sumber yang layak dipercaya untuk dapat digunakan sebagai bahan pertimbangan dalam melakukan amalamal keagamaan dalam mengambil keputusan dan pertimbangan bagi penentuan sikap dan tingkah laku keberagamaan. Layanan informasi agama bertujuan membekali umat dengan berbagai hal yang sangat berguna bagi kehidupan ini. c) Layanan Penempatan dan Penyaluran Bakat Keberagamaan Layanan penempatan dan penyaluran bakat keberagamaan adalah layanan yang memungkinkan umat beragama memperoleh penempatan dan penyaluran yang tepat dan benar dalam pengembangan hidup keberagamaan sesuai dengan potensi, minat, bakat, situasi, dan kondisi pribadi manusia beragama yang bersangkutan.

d) Layanan Bimbingan Pembelajaran/ Pengajian Agama

Layanan bimbingan pembelajaran/ pengajian agama adalah layanan yang memungkinkan orang beragama mengembangkan sikap dan kebiasaan belajar agama yang baik, materi pengajian agama yang cocok dengan kecepatan dan kesulitan belajar agama, serta berbagai aspek tujuan dan kegiatan belajar agama lainnya yang berguna bagi kehidupan keberagamaan.

e) Layanan Konseling Agama Perorangan Layanan konseling agama perorangan adalah layanan yang memungkinkan orang beragama mendapatkan layanan langsung tatap muka dengan konselor agama dalam rangka pengentasan permasalahan agama yang di hadapi klien. Permasalahan keberagamaan yang dapat dilayani melalui konseling agama 
perorangan ini meliputi semua aspek keagamaan. Konselor agama melayani klien secara individual.

f) Layanan Bimbingan Agama Kelompok Layanan bimbingan agama kelompok adalah layanan yang memungkinkan sejumlah (sekelompok) orang yang beragama memperoleh kesempatan bagi pembahasan dan pengentasan masalah keberagamaan yang mereka alami masing-masing melalui suasana dan dinamika kelompok.

g) Layanan Konseling Agama Kelompok Layanan konseling agama kelompok adalah layanan yang dimaksudkan untuk memungkinkan sejumlah orang yang beragama secara berjamaah memperoleh bahan dan informasi dari nara sumber tertentu tentang masalah hidup keberagamaan mereka yang dapat dijadikan bahan pertimbangan dalam menentukan sikap dan tingkah laku keberagamaan.

\section{Penutup}

Lanjut usia dapat dikatakan sebagai usia emas karena tidak semua orang dapat mencapai usia lanjut, maka jika seseorang telah berusia lanjut akan memerlukan tindakan keperawatan yang lebih, baik yang bersifat promotif maupun preventif, agar ia dapat menikmati masa usia emas serta menjadi usia lanjut yang berguna dan bahagia. Sebaliknya usia lanjut bila tidak ada perawatan yang intensif dari keluarganya maka ia tidak dapat menikmati masa usia emasnya dengan bahagia.

Sementara yang dikatakan usia lanjut adalah individu yang sudah berumur 60-65 tahun ke atas, artinya individu yang telah memiliki daya kemampuan untuk hidup dan kepekaan secara individual yang lemah, baik lemah terhadap kondisi fisik maupun lemah menyesuaikan dengan lingkungannya.

Kondisi yang ada pada lansia cenderung berpotensi menimbulkan masalah kesehatan fisik maupun kesehatan jiwa. Oleh karena itu sangat diperlukan bimbingan dan konseling Islam agar dapat membantu mengentaskan permasalahan yang dihadapinya. Sehingga lansia dalam kehidupan kesehariannya menjadi efektif yang akhirnya dapat berfikir bahwa ia masih berguna dan dibutuhkan orang lain dan memiliki potensi dengan tetap berpegang pada nilai-nilai Islam.

\section{Endnote}

${ }^{1}$ Santrock, John W. Life-Span Development. (Perkembangan Masa Hidup).Jilid II. Edisi Ke lima.Jakarta: Renika Cipta.2004.

${ }^{2}$ Elizabeth B. Hurlock, Psikologi Perkembangan: Suatu Pendekatan Sepanjang Rentang Kehidupan, (Jakarta: Erlangga, 1980), h.385

${ }^{3}$ Elida Prayito dan Erlamsyah. Psikologi Perkembangan Orang Dewasa. Padang: UNP Perss.2002.h.79 
${ }^{4}$ Elizabeth B. Hurlock, Psikologi Perkembangan: Suatu Pendekatan Sepanjang Rentang Kehidupan, (Jakarta: Erlangga, 1980), h.409

${ }^{5}$ Elizabeth B. Hurlock, Psikologi Perkembangan: Suatu Pendekatan Sepanjang Rentang Kehidupan, (Jakarta: Erlangga, 1980), h.413

${ }^{6}$ Erhamwilda. Konseling Islami.Yogyakarta: Graha Ilmu. 2009 h. 87

${ }^{7}$ http://www.psychologymania.com/ 2013/01/pola-hidup-sehat-lansia.html.diakses 8 Oktober 2017

${ }^{8}$ http://www.psychologymania.com/ 2013/01/pola-hidup-sehat-lansia.html. diakses 8 Oktober 2017

9 http://www.psychologymania.com/ 2013/01/pola-hidup-sehat-lansia.html. diakses 8 Oktober 2017
${ }^{10}$ Faqih, Ainur Rahim. Bimbingan dan Konseling dalam Islam. Yogyakarta: UII Press.2011.h. 23

${ }^{11}$ Asyim,Farid,Bimbingan dan Konseling Religius. Jogjakarta. Ar-ruzz Media.2010.h 67

${ }^{12}$ Departemen Agama RI. (1984). Al Qur'an dan terjemahannya. Jakarta : Bumi Restu.

${ }^{13}$ Departemen Agama RI. (1984). Al Qur'an dan terjemahannya. Jakarta : Bumi Restu.

${ }^{14}$ Hasyim,Farid,Bimbingan dan Konseling Religius. Jogjakarta. Ar-ruzz Media.2010.h 67

${ }^{15}$ Hamdani. Bimbingan dan Penyuluhan. 2012. Bandung. CV.Pustaka Setia

${ }^{16}$ Yahya Jaya; Bimbingan dan Konseling Agama. Padang: Angkasa Raya, 2004, hal. 108 